\title{
Introduction: Symposium on William Easterly's The Tyranny of Experts
}

\author{
Peter J. Boettke ${ }^{1} \cdot$ Christopher J. Coyne ${ }^{1}$
}

Published online: 24 July 2015

(C) Springer Science+Business Media New York 2015

With his books The Elusive Quest for Growth and The White Man's Burden, William Easterly significantly changed the terms of the debate over the role of government and foreign aid in addressing poverty and underdevelopment. It is important to stress, however, that Easterly's work is not just a critique of efforts at development planning due to perverse incentives, bureaucratic bottlenecks, and errors in information. Rather, his writings contain a deep understanding of the role of the entrepreneurial market process in lifting individuals out of poverty and producing a social order of freedom, dignity, peace, and prosperity. Development follows from a society of free and responsible individuals who participate in a market economy based on profit and loss; who participate in a political regime governed by principle, not privilege; and who live in a society that exhibits neither discrimination nor dominion. Easterly is one of the clearest voices in economics today for how the free enterprise system is a catalyst for human betterment.

In The Tyranny of Experts, Easterly develops the argument regarding the importance of liberty, freedom, equality, rights, and democracy for human flourishing in great detail. In doing so he indicts the Western aid establishment for promoting autocrats, rather than merely tolerating them, in their efforts to engage in development policies. The technocratic approach to development, Easterly contends, fails to appreciate that the main source of the tragic poverty that exists throughout the less developed world is a direct consequence of the unchecked power of governments. This unconstrained power allows the political elite to act in a manner which runs counter to the interests of the poor who lack basic rights. Development occurs, Easterly argues, by unleashing the potential of individuals through the recognition of their rights to their persons and their projects. The bottom-up, spontaneous, uncoordinated actions of the multitude of

Christopher J. Coyne

ccoyne3@gmu.edu

Peter J. Boettke

pboettke@gmu.edu

1 Department of Economics, George Mason University, Fairfax, VA 22030, USA 
diverse actors, as opposed to top-down initiatives involving the state or outside donors, is the ultimate source of human flourishing.

Easterly has produced a work that addresses economic development not as a technical problem in need of an engineering solution, but as a deeply moral question that requires not only economics, but also historical perspective, a comparative political focus on structures, and philosophic reflection on the nature of what constitutes the "good society." Fittingly, we have asked three scholars representing the disciplines of philosophy (Loren Lomasky), politics (Jack Goldstone), and economics (Angus Deaton) to share their reactions to The Tyranny of Experts. We have also provided space for Easterly to respond to these commentaries. We hope this discussion will excite the minds of our readers to continue to grapple with the difficult, but critically important, questions associated with serious inquiry into the nature and causes of the wealth and poverty of nations and the meaning of the answers offered for the liberty, dignity, and flourishing of humanity. 